Tomasz M. Dąbek OSB

\title{
Rok św. Pawła w rzymskiej bazylice św. Pawła za Murami
}

Podczas wakacji 2008 roku pomagałem współbraciom - benedyktynom z klasztoru przy bazylice św. Pawła za Murami w Rzymie - w posłudze w konfesjonale. Klasztor należy do kongregacji Monte Cassino, ale od kilku lat wspólnota jest międzynarodowa: przełożonym jest o. Edmund Power z Anglii, jego zastępcą Austriak, prócz Włochów są też mnisi z Indii, Cejlonu, Burkina Faso, Brazylii, Meksyku, Gwatemali i Kanady oraz kapłan-student z Kenii. Na Rok św. Pawła przybywali także benedyktyni z różnych klasztorów z całego świata. Podczas mego stosunkowo krótkiego pobytu (4 VIII-12 IX) posługiwali wyznaczeni na cały rok kapłani z Irlandii, Brazylii, Indii, Polski (współbracia z klasztoru Biskupów k. Nysy założonego przez o. Ludwika Mycielskiego OSB w 1987 roku), przez kilka tygodni był też Francuz. Spowiednicy byli do dyspozycji w godzinach $7.00-12.30$ oraz 16.00-18.30 (niektórzy gorliwi przychodzili wcześniej - ok. 15.00). Opiekujący się bazyliką kard. Andrea di Montezemolo często przed południem przechadzał się po bazylice, czuwał nad porządkiem posługi spowiedniczej w prawej nawie, a w razie potrzeby także w innych miejscach bazyliki.

O uroczystych obchodach pisało „L'Osservatore Romano” oraz inne pisma katolickie. Ja zwrócę uwagę na powszedni dzień w bazylice oraz na wydarzenia, które miały miejsce podczas mojego pobytu, czyli w drugiej połowie pierwszego kwartału Roku św. Pawła.

Przed konfesją codziennie po nieszporach śpiewano hymn i antyfonę o św. Pawle, w piątek po południu celebrowano nieszpory ku czci św. Pawła. Homilie niedzielne poświęcone były w znacznej mierze rozważaniu życia i nauki św. Pawła. Msze święte dla pielgrzymów celebrowali benedyktyni o $8.00,9.00,10.30$ i 18.00 , często duże grupy pielgrzymów miały dodatkowe celebry pod przewodnictwem ich duszpasterzy, nierzadko biskupów.

Liturgia godzin sprawowana była częściowo w zakonnej kaplicy pod wezwaniem św. Grzegorza VII, której ściana jest wspólna z prawą ścianą bazyliki (godzina czytań, modlitwa w ciągu dnia, kompleta), częściowo w ab- 
sydzie bazyliki (msza święta w dni powszednie o 6.35 z jutrznią, w niedziele o 10.30, nieszpory o 17.00). Jeśli w absydzie miała miejsce celebra dużej grupy pielgrzymów, wówczas jutrznia niedzielna i nieszpory sprawowane były w kaplicy św. Wawrzyńca po prawej stronie absydy. Współbracia korzystali z włoskich brewiarzy monastycznych, w których psałterz jest odmawiany w ciągu tygodnia w układzie tematycznym psalmów. Niedzielna godzina czytań trwała około godziny zegarowej (czasem nieco dłużej), podczas seksty odmawiano także psalmy tercji i nony przypadające na dany dzień tygodnia. Psalmy były odmawiane albo śpiewane po włosku, hymny i antyfony - po łacinie. Podczas mszy śpiewano gregoriańskie części stałe i zmienne.

Włoska poczta urządziła w sali koło krużganka wystawę znaczków związanych z apostolską działalnością św. Pawła w dniach 28 sierpnia-14 września 2008 roku. Plansze pokazywały podróże św. Pawła i miejsca związane z jego działalnością oraz znaczki z różnych krajów. Były też figury ludzi z czasów św. Pawła.

Od 9 do 13 września 2008 roku odbywało się pod przewodnictwem prof. Jacquesa Schlossera ze Strasbourga 20. Colloqium Oecumenicum Paulinum poświęcone jedności Kościoła w Listach św. Pawła. Sekretariat prowadził o. László T. Simon OSB z węgierskiego opactwa Pannonhalma, wykładowca Pisma Świętego w benedyktyńskim Papieskim Ateneum św. Anzelma.

W tegorocznym kolokwium udział wzięli uczeni o międzynarodowej renomie pochodzący z różnych krajów i tradycji chrześcijańskich:

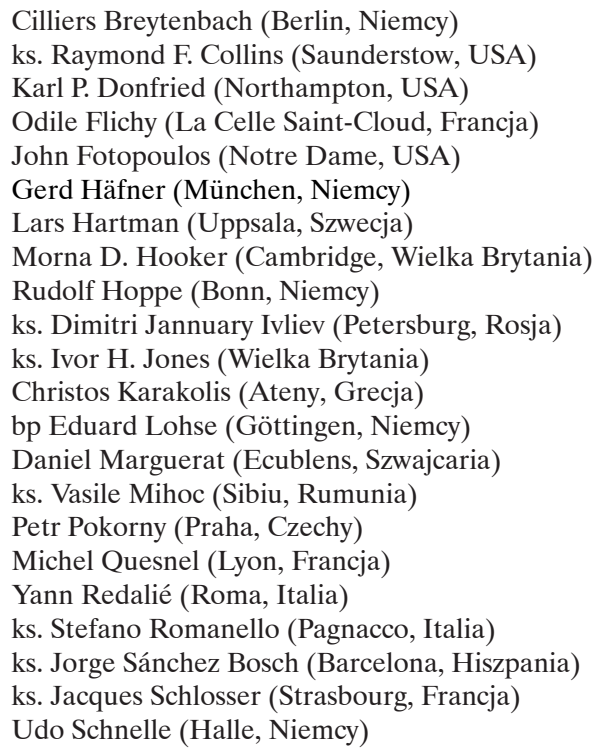


László T. Simon OSB (Roma, Italia)

Benoît Standaert OSB (Roma, Italia)

Gregory Tatum OP (Jerusalem, Izrael)

Christopher M. Tuckett (Oxford, Wielka Brytania)

Johan H. Vos (Amstel, Holandia)

Michael Wolter (Bonn, Niemcy)

W trakcie kolokwium wygłoszone zostały referaty podejmujące tematykę jedności chrześcijan w ujęciu św. Pawła.

We wtorek 9 września pierwszy wystąpił Udo Schnelle z referatem po niemiecku Jedyność Boga i jedność chrześcijan w ujęciu Pawła. Aby szczegółowy problem jedności chrześcijan zobaczyć na szerszym tle stosunków pomiędzy monoteizmem i uniwersalizmem oraz jednocześnie podkreślić więź chrześcijaństwa z judaizmem, prelegent odwołał się do Listu do Rzymian, gdzie te problemy pojawiają się najpierw w rozdziałach 1-3, potem są podjęte w podobnych słowach, tyle że $\mathrm{z}$ akcentem na chrystologię w 10, 5-13 i wreszcie zwieńczone w 15, 7-13 z wyraźnym nawiązaniem do tematu wypełnionej obietnicy.

Po nim głos zabrał ks. Raymond F. Collins. W swoim wystąpieniu w języku angielskim Metafora budowli i jej kościelne odniesienie pokazał na podstawie tekstu 1 Kor 3, 10-22 i jego relektury w Ef 2,19-22, jak Paweł wobec rzeczywistości podziału i potrzeby jedności akcentuje rolę Chrystusa jako fundamentu domu.

W środę 10 września Gerd Häffner wygłosił po niemiecku referat Pawtowa teologia chrztu, w którym skoncentrował się na więzi chrztu i jedności, którą najbardziej widać w Ga 3, 26-29; 4, 1-7.

Natomiast Christopher M. Tuckett mówił po angielsku na temat $\mathrm{Me}$ tafory ciała w jej kościelnym zastosowaniu. Zwrócił uwage, że metafora ta jest bardzo przydatna w refleksji na temat jedności, i przedstawił jej rozwój w pismach św. Pawła, począwszy od 1 Kor 12, 12-27 poprzez Rz 12, 4-5 i Kol 1, 18. 24; 3, 25 aż po Ef 4, 7-16, gdzie jest połączona z obrazem budowli.

W czwartek 11 września John Fotopoulos wygłosił po angielsku referat Eucharystia, sakrament jedności. Zaznaczył, że tematu Eucharystii nie można pominąć w dyskusji na temat jedności Kościoła, i omówił problem koinonii w kontekście Eucharystii na podstawie 1 Kor 10, 14-18; 11, 17-33.

W piątek 12 września Daniel Marguerat miał po francusku referat Usprawiedliwienie przez wiarę. Zauważył, że usprawiedliwienie jest w pewnej mierze konsekwencją jedyności Boga, ale że nie można pomijać w nim aspektu chrystologicznego widocznego najbardziej w Flp 3, 7-11 i Ga 2, 15-21, a także w Rz 3, 21-26. Usprawiedliwienie w Chrystusie daje podstawę do budowania prawdziwej jedności w Kościele. 
Na koniec w sobotę 13 września ks. Stefano Romanello zaprezentował po włosku temat Jedność we wspólnocie lokalnej: List do Filipian. Uwypuklił, że list ten, zwłaszcza 1, 27-2, 4, podkreśla konieczność podstawowej i stałej troski o zachowanie wewnętrznej jedności we wspólnotach chrześcijańskich.

Ekumeniczne kolokwia Pawłowe rozpoczęto w 1970 roku. Inicjatywa ma więc już czterdziestoletnią tradycję. Spotkania odbywają się co dwa lata i gromadzą wybitnych specjalistów - badaczy Nowego Testamentu, zwłaszcza pism św. Pawła, z różnych wyznań chrześcijańskich. W ostatnim kolokwium niektórzy protestanci uczestniczyli razem ze swymi żonami, jedna z par obchodziła 48. rocznicę ślubu. Byli także prawosławni. Rosyjski kapłan kilkakrotnie pobożnie uczestniczył we mszy świętej i w nieszporach poza normalnym programem spotkań, który obejmował każdego dnia przed obiadem sekstę, a w piątek 12 września - uroczyste nieszpory ekumeniczne o 18.00.

Warto przytoczyć tytuły tomów z serii Benedictina zawierających materiały z wcześniejszych kolokwiów. Redagowane one były w różnych językach najpierw przez o. Lorenzo De Lorenzi OSB z opactwa św. Pawła za Murami, a potem przez innych, także wybitnych biblistów:

1. The Law and the Spirit in Rom 7 and 8 (1976)

2. Battesimo e giustizia in Rom 6 e 8 (1974)

3. Die Israelfrage nach Röm 9-11 (1977)

4. Dimensions de la vie chrétienne (Rm 12-13) (1979)

5. Paolo e una Chiesa divisa (1 Co 1-4) (1980)

6. Freedom and Love. The Guide for Christian Life (1 Co 8-10; Rm 14-15) (1981)

7. Charisma und Agape (1 Ko 12-14) (1983)

8. Résurrection du Christ et des Chrétiens (1 Co 15) (1985)

9. Paolo ministro del Nuovo Testamento (2 Co 2, 14-4, 6) (1987)

10. The Diakonia of the Spirit (2 Co 7: 4-7: 4) (1989)

11. Verteidigung und Begründung des apostolischen Amtes (2 Kor 10-13) (1992)

12. The Truth of the Gospel (Galatians 1: 1-4: 11) (1993)

13. La foi agissant par l'amour (Galates 4, 12-6, 16) (1996)

14. Per me il vivere è Cristo (Filippesi 1, 1-3, 21) (2001)

15. Not in the Word Alone. The First Epistle to the Thessalonians (2003)

16. „Le Christ tuot et en tous” (Col. 3, 11). L'épître aux Colossiens (2003)

17. Ethik als Angewandte Ekklesiologie. Der Brief an die Epheser (2005).

18. 1 Timothy Reconsidered (2008).

Wydarzenia naukowe i kulturalne, które tu opisano, uzupełniają nieustanną modlitwę za wstawiennictwem wielkiego Apostoła Narodów, mistrza chrześcijańskiego życia, oraz posługę duszpasterską, która ma pomóc współczesnym ludziom zrozumieć sens życia i sposób postępowania wynikający z wiary, by mogli osiągnąć prawdziwy pokój i szczęście. 